\title{
DİETİLSTİLBSTROL UYGULANAN SIÇANLARIN BÖBREK, DALAK, KALP VE BEYİNLERİNDE BAZI ENZİM DÜZEYLERİNİN İNCELENMESİ
}

\author{
THE INVESTIGATION OF SOME ENZYME LEVELS IN THE \\ KIDNEY, SPLEEN, HEART AND BRAIN OF RATS TO WHICH \\ DIETHYLSTILBESTROL IS ADMINISTERED
}

\author{
İsmihan GÖZE*, İzzet YELKOVAN**, Sevtap BAKIR*** Ziynet ÇINAR**** \\ * Cumhuriyet Üniversitesi Sağlık Hizmetleri Meslek Yüksek Okulu .SIVAS \\ **Cumhuriyet Üniversitesi Tıp Fakültesi Tıbbi Biyoloji Anabilim Dalı, SİVAS \\ ***Cumhuriyet Üniversitesi Tıp Fakültesi Biyokimya Anabilim Dalı, SIVAS \\ **** Cumhuriyet Üniversitesi Tıp Fakültesi Biyoistatistik Anabilim Dalı, SIVAS
}

58140-SİVAS

\section{ÖZET}

Dietilstilbestrol'un (DES) total protein ve dokulardaki enzim parametreleri üzerindeki olası değişimlerini izlemeyi amaçladığımı çalışmamızda, gebe sıçanlara gebeliğin 2. gününden itibaren 19 gün süreyle $0,4 \mu \mathrm{g} / \mathrm{g} /$ gün (yaklaşık $60 \mu \mathrm{g} / \mathrm{rat}$ ) dozunda DES oral gavaj yoluyla verildi. Denekler gebeliğin son günü servikal dislokasyonla öldürüldü. Böbrek, dalak, beyin ve kalplerinden hazırlanan homojenatlarda total Protein (TP) ile alanin amino transferaz (ALT), laktat dehidrogenaz (LDH), Gama glutamik transpeptidaz (GGT), alkalen fosfat az (ALP), aspartat amino transaminaz (AST) ve glutatyon -stransferaz (GST) enzim akliviteleri ölçüldü.. GST aktivitesi spektrofotometrik yöntemle çalışlld diğer tüm enzim aktiviteleri ise Ciba Corning Express Plus otoanalizörde ölçüldü. Elde edilen sonuçlar, kontrol grubu sıçanların enzim aktivite sonuçları ile karşılaştırıldı. Yapılan istatistiksel analizde denek enzim aktivite ölçümleri kontrol grupları ile karşılaştırıldığında dalakta ALP hariç tüm enzim gruplarında, gruplar arasıfarklllik anlamsiz olarak bulundu (p>0,05). Böbreklerde TP, ALT, LDH ve GST, kalpte $A L T$ ve $A S T(u=4 ; p<0,05)$ Beyinde ise ALT, ALP ve GGTenzim aktiviteleri yönünden gruplar arası fark istatistiksel yönden anlamlı $(p<0,05)$ bulunurken diğer gruplarda anlaml fark bulunamadı $(p>0,05)$. Dalak hariç incelenen diğer dokularda, bazı sitoplazmik enzim aktivitelerinin değişikliğe uğramış olması, DES'in pek çok metabolikyolu etkileyerek biyomoleküllerle etkileştiğini düşündürdü.

Anahtar Kelimeler: DES, ALT, LDH, ALP, GGT, TP, AST, GST, enzim, slçan 


\begin{abstract}
In this study, we aimed to observe possible changes in enzyme activities and total protein levels in tissues of diethylstilbestrol (DES) at the dose of $0.4 \mu \mathrm{g} / \mathrm{g} /$ day (60 $\mu \mathrm{g} / \mathrm{rat}$ ) had orally been given to the pregnant rats since two day of the pregnancy for 19. days by oral gavage. Rats were killed by cervical dislocation on the last day of pregnancy. In prepared homogenates from spleen, kidney, heart and brain tissues total protein (TP), alanin amino transferase (ALT), laktate dehidrogenase (LDH), alkaline fosfatase (ALP), gamma glutamik transpeptidaz (GGT), aspartat amino transaminaz (AST) enzymes were measured by Ciba Corning Express Plus autoanalyzer. GST enzyme was studied by spectrofotometric assay. The data of experimental group was compared with those of control rats. In the statistical analysis, there were found insignificant differences between experimental group and control group in terms of enzymes except for ALP in spleen $(p>0,05)$. There were found statistically significant differences in experimental group compared to control rats in kidney TP, ALT, LDH, GST in heart ALT, $A S T$ and brain ALT, ALP and GGT enzymes ( $p<0,05)$, but the other enzyme activities were not showed significant differences between two group ( $p>0,05)$. We think that DES can be affect many metabolic ways because of changed some stoplazmic enzyme activities in the tissues.
\end{abstract}

Key words: DES, ALT,LDH,ALP, GGT, TP ,AST, GST, enzyme.rat

\title{
GİRIŞ̧
}

Stilbenlerin alt ünitesini oluşturan dietistilbestrol (DES), çok stabil yapılıdır ve toksik etkisi uzun süre devam eder $(1,2)$. İlk sentezlendiğinden beri hayvancılık ve klinik alanda geniş kullanım sahası bulmuştur. Sadece A.B.D. de 1971den bu güne kadar yaklaşık 2.000.000. kadının abortusu engellemek için DES kullandığı belirtilmiştir (3 ). DES ile fetal dönemde etkilenen kız çocuklarda vagina ve serviks' te adenozis, berrak hücreli adenokarsinoma riskinin normal populasyona göre yüksek olduğu, erkek çocuklarda ise azoospermi ve jinekomasti etkileri bildirilmiştir (4-9).

Anabolizan etkisi nedeni ile hayvancılık alanında kullanılmış ancak karsinojenik etkilerinin tesbitinden sonra bu amaçla kullanımı bir çok ülkede yasaklanmıştır $(2,9)$. Yurdumuza ithal edilen etlerde anabolizan denetimi zorunludur, ancak aynı kontrolün yerli üretimde yapılması için yasal tedbirler yoktur ve etler, et ürünleri ve yemler bu yönde denetlenmemektedir $(4,10)$. Dolayısı ile karsinojenik etkili DES ve metabolitleri besin zinciri yolu ile her gün binlerce insana ulaşmaktadır. 
DES' in enzimlere etkileri üzerinde de bazı araştırmalar mevcuttur, adenozin deaminaz (ADA), peptidil arjinin deaminaz, peroksidaz gibi enzim tepkimeleri izlenmiştir (11-15). Organizmaya alınan DES' in kan lipid miktarında değişime neden olup bazı organ ve dokularda yağlanmayı artırdığı, damarlarda yağlanma ve dejenerasyon oluşturduğu bildirilmiştir $(16,17)$. Araştırmamızda karsinojenik etkilerinin yanısıra hormon ve enzim salınımında değişime yol açan DES' in dalak, böbrekler, beyin ve kalpde total protein değeri ve bazı sitoplazmik enzimlerin aktivitelerine etkisi ve olası değişimleri izlemek ayrıca, ksenobiyotik etkisinden dolayı DES' in biyotransformasyonunun glutatyon-s- transferaz (GST) aktivitesini değiştirip değiştirmediğini belirlemek amaçlanmıştır.

\section{MATERYAL-METOD}

Deneylerde 4 haftalık yaklaşık 150 gr ağırlığında 6 adet sıçan kullanıldı. ( Rattus Norvegicus var.albino). Bunların hepsine gebeliğin ikinci gününden itibaren 19 gün $\quad 0,4 \mu \mathrm{g} / \mathrm{g} /$ gün $(60 \mu \mathrm{g} / \mathrm{rat})$ dozunda mısır yağında çözünen DES oral gavaj yolu ile verildi. Kontrol grubu da denek grubuna paralel sürelerde çalışıldı. Denek ve kontrol grubu sıçanların tümü gebeliğin 20. gününde servikal dislokasyonla öldürülüp böbrek, dalak, beyin ve kalpleri alındı.

Organlar 0,15 M KCI ile iyice yıkandı. Kaba terazide tartıldı ve 1 gramlık parçalar özütleme için kullanıldı. 1:3 (ağırlık/hacim) oranında 0,15 M KCI ilave edilip 1400 devir/dakika hızla dönen teflon cam özütleyicide (B.Braun) üç vuruş yapılarak parçalandı. Elde edilen homojenat soğutmalı ve vakumlu olan Beckman Model J 2 Santrifüj de 4800 g' de 15 dakika santrifüje edildi. Elde edilen supernatanda GST dışındaki enzim aktiviteleri Ciba Corning Express Plus otoanalizöründe ölçüldü. Bioklinikadan temin edilen standard otoanalizör kitleri kullanıldı (18). GST enzim aktivitesi ise glutatyonun substratı ile arasındaki tiyoeter bağı oluşumunun 340 340nm'de spektrofotometrede ölçülmesi ile saptandı (19). İstatistiksel değerlendirme, denek sayısının $(\mathrm{n}<30)$ az olması nedeni ile bağımsız iki gruptan ölçümle elde edilen veriler karşılaştırılırken tercih edilen parametrik olmayan Mann-Whitney "u" testi ile yapıldı (20).

\section{SONUÇ VE TARTIŞMA}

19 gün DES verilen sıçanların dalak, böbrek, kalp ve beyin homojenatlarında saptanan TP ve enzim aktivite değerlerinin ( $\mathrm{U} / \mathrm{mg}$ protein) istatiksel analizlerine ait veriler Tablo 1 , Tablo 2, Tablo 3 ve 4' de gösterilmiştir. 
Denek gebe sıçanların dalak homojenatında ölçülen TP ve enzim aktivite değerleri, kontrol grubu değerleri Mann Whitney "u" testi ile karşılaştırıldığında ALP hariç tüm parametrelerde gruplar arası farklılık istatistiksel yönden anlamsız bulundu $(\mathrm{p}>0,05)$ (Tablo 1)

TABLO 1. Denek ve kontrol grubu sıçanların dalakları arasında total protein ile enzim aktivitelerinin karşılaştırılması.

\begin{tabular}{|l|l|l|l|}
\hline T.P ve Enzimler & $\begin{array}{l}\text { X+Sx } \\
\text { DENEK n:6 }\end{array}$ & $\begin{array}{l}\text { X+Sx } \\
\text { KONTROL n:6 }\end{array}$ & SONUÇ \\
\hline $\begin{array}{l}\text { total protein - T.P } \\
\text { U/mg protein }\end{array}$ & $1,32+0,11$ & $1,03+0,09$ & $\mathrm{U}=20 ; \mathrm{p}>0,05$ \\
\hline $\begin{array}{l}\text { alkalen fosfataz- ALP } \\
\text { U/mg protein }\end{array}$ & $243,33+61,14$ & $60+13,17$ & $\mathrm{U}=30 ; \mathrm{p}<0,05^{*}$ \\
\hline $\begin{array}{l}\text { alanin transferaz-ALT } \\
\text { U/mg protein }\end{array}$ & $613,3+143,17$ & $682,3+155,5$ & $\mathrm{U}=20 ; \mathrm{p}>0,05$ \\
\hline $\begin{array}{l}\text { laktat dehidrogenaz-LDH } \\
\text { U/mg protein }\end{array}$ & $27693,3+2957,1$ & $21883,3+4011,5$ & $\mathrm{U}=20 ; \mathrm{p}>0,05$ \\
\hline $\begin{array}{l}\text { gamaglutamik transferaz-GGT } \\
\text { U/mg protein }\end{array}$ & $2993,3+22,31$ & $2813+480,4$ & $\mathrm{U}=24 ; \mathrm{p}>0,05$ \\
\hline $\begin{array}{l}\text { aspartat transaminaz-AST U/mg } \\
\text { protein }\end{array}$ & $4606,6+276,4$ & $4029+1046,5$ & $\mathrm{U}=20 ; \mathrm{p}>0,05$ \\
\hline $\begin{array}{l}\text { glutatyon S transferaz-GST } \\
\text { U/mg protein }\end{array}$ & $0,02+0,00$ & $0,02+0,00$ & $\mathrm{U}=24, \mathrm{p}>0,05$ \\
\hline
\end{tabular}

Böbrek homojenatında yapılan ölçümde ise TP $(U=36 ; p<0,05)$, ALT $(U=36 ; p<0,05)$, LDH $(\mathrm{U}=36 ; \mathrm{p}<0,05)$ ve $\mathrm{GST}(\mathrm{U}=36 ; \mathrm{p}<0,05)$ aktivitelerinde anlamlı değişim izlendi (Tablo 2).

TABLO 2. Denek ve kontrol grubu sıçanların böbrekleri arasında total protein ile enzim aktivitelerinin karşılaştırılması.

\begin{tabular}{|l|l|l|l|}
\hline T.P ve Enzimler & $\begin{array}{l}\mathrm{X}+\mathrm{Sx} \\
\text { DENEK } n=6\end{array}$ & $\begin{array}{l}\text { X+Sx } \\
\text { KONTROL } n=6\end{array}$ & SONUÇ \\
\hline $\begin{array}{l}\text { Total protein-TP } \\
\text { U/mg protein }\end{array}$ & $1,37+0,15$ & $2,07+0,15$ & $\mathrm{U}=36 ; \mathrm{p}<0,05^{*}$ \\
\hline $\begin{array}{l}\text { alkalen fosfataz-ALP } \\
\text { U/mg protein }\end{array}$ & $3280+536,26$ & $3320+542,01$ & $\mathrm{U}=24 ; \mathrm{p}>0,05$ \\
\hline $\begin{array}{l}\text { alanin transferaz-ALT } \\
\text { U/mg protein }\end{array}$ & $2376,6+289,7$ & $8900+1081$ & $\mathrm{U}=36 ; \mathrm{p}<0,05^{*}$ \\
\hline $\begin{array}{l}\text { laktat dehidrogenaz-LDH } \\
\text { U/mg protein }\end{array}$ & $37096,6+5731$ & $82748,3+8439,3$ & $\mathrm{U}=36 ; \mathrm{p}<0,05^{*}$ \\
\hline $\begin{array}{l}\text { gamaglutamik transferaz-GGT } \\
\mathrm{U} / \mathrm{mg} \text { protein }\end{array}$ & $2993,3+223,1$ & $2813+480,4$ & $\mathrm{U}=24 ; \mathrm{p}>0,05$ \\
\hline $\begin{array}{l}\text { aspartat transaminaz-AST } \\
\mathrm{U} / m g \text { protein }\end{array}$ & $22646,6+5731$ & $35491,6+4074,7$ & $\mathrm{U}=28 ; \mathrm{p}>0,05$ \\
\hline $\begin{array}{l}\text { glutatyon S transferaz-GST } \\
\text { U/mg protein }\end{array}$ & $1,37+0,08$ & $0,2+0,04$ & $\mathrm{U}=36 ; \mathrm{p}<0,05^{*}$ \\
\hline
\end{tabular}


Kalp homojenatında yapılan değerlendirmede ise ALT $(\mathrm{U}=36 ; \mathrm{p}<0,05)$ ve AST $(\mathrm{U}=32 ; \mathrm{p}<0,05)$ enzim aktivitelerinde anlamlı değişim izlendi (Tablo 3 ).

TABLO 3. Denek ve kontrol grubu sıçanların kalpleri arasında total protein ile enzim aktivitelerinin karşılaştırılması.

\begin{tabular}{|l|l|l|l|}
\hline T.P ve Enzimler & $\begin{array}{l}\mathrm{X}+\mathrm{Sx} \\
\text { DENEK } n=6\end{array}$ & $\begin{array}{l}\mathrm{X}+\mathrm{Sx} \\
\text { KONTROL } \mathrm{n}=6\end{array}$ & $\mathrm{SONUÇ}$ \\
\hline $\begin{array}{l}\text { Total protein-TP } \\
\mathrm{U} / m \text { g protein }\end{array}$ & $1,17+0,01$ & $1,27+0,04$ & $\mathrm{u}=24 ; \mathrm{p}>0,05$ \\
\hline $\begin{array}{l}\text { Alkalen fosfataz-ALP } \\
\text { U/mg protein }\end{array}$ & $900+189,8$ & $394+43,36$ & $\mathrm{u}=28 ; \mathrm{p}>0,05$ \\
\hline $\begin{array}{l}\text { Alanin transferaz-ALT } \\
\text { U/mg protein }\end{array}$ & $1747,67+99,9$ & $14950+724,1$ & $\mathrm{u}=36 ; \mathrm{p}<0,05^{*}$ \\
\hline $\begin{array}{l}\text { Laktat dehidrogenaz-LDH } \\
\text { U/mg protein }\end{array}$ & $11066+10962$ & $130566+953,1$ & $\mathrm{u}=24 ; \mathrm{p}>0,05$ \\
\hline $\begin{array}{l}\text { Gamaglutamik transferaz-GGT } \\
\mathrm{U} / m g \text { protein }\end{array}$ & $33,33+4,22$ & $30,1+3,3$ & $\mathrm{u}=20 ; \mathrm{p}>0,05$ \\
\hline $\begin{array}{l}\text { Aspartat transaminaz-AST } \\
\mathrm{U} / m g \text { protein }\end{array}$ & $63000+1316,5$ & $69216,6+1770,1$ & $\mathrm{u}=32 ; \mathrm{p}<0,05^{*}$ \\
\hline $\begin{array}{l}\text { Glutatyon S transferaz-GST } \\
\text { U/mg protein }\end{array}$ & $0,03+0,01$ & $0,01+0,0$ & $\mathrm{u}=24 ; \mathrm{p}>0,05$ \\
\hline
\end{tabular}

Beyinden hazırlanan homojenatta ise ALT $(\mathrm{U}=36 ; \mathrm{p}<0,05)$, ALP $(\mathrm{U}=32 ; \mathrm{p}<0,05) \quad$ ve GGT $(\mathrm{U}=36 ; \mathrm{p}<0,05)$ aktivite değişimi izlendi (Tablo 4)..

TABLO 4. Denek ve kontrol grubu sıçanların beyinleri arasında total protein ile enzim aktivitelerinin karşılaştırılması.

\begin{tabular}{|l|l|l|l|}
\hline T.P ve Enzimler & $\begin{array}{l}\mathrm{X}+\mathrm{Sx} \\
\text { DENEK } n=6\end{array}$ & $\begin{array}{l}\mathrm{X}+\mathrm{Sx} \\
\text { KONTROL } \mathrm{n}=6\end{array}$ & SONUÇ \\
\hline $\begin{array}{l}\text { total protein-TP } \\
\mathrm{U} / m g \text { protein }\end{array}$ & $1,07+0,26$ & $0,70+0,04$ & $\mathrm{U}=20 ; \mathrm{p}>0,05$ \\
\hline $\begin{array}{l}\text { alkalen fosfataz-ALP } \\
\mathrm{U} / \mathrm{mg} \text { protein }\end{array}$ & $670+43,05$ & $780+21,91$ & $\mathrm{U}=32 ; \mathrm{p}<0,05^{*}$ \\
\hline $\begin{array}{l}\text { alanin transferaz-ALT } \\
\mathrm{U} / m \text { protein }\end{array}$ & $828,6+86,4$ & $1604,6+42,28$ & $\mathrm{U}=36 ; \mathrm{p}<0,05^{*}$ \\
\hline $\begin{array}{l}\text { laktat dehidrogenaz-LDH } \\
\mathrm{U} / \mathrm{mg} \text { protein }\end{array}$ & $54320+8122,6$ & $41516,6+2220$ & $\mathrm{U}=24, \mathrm{p}>0,05$ \\
\hline $\begin{array}{l}\text { gamaglutamik transferaz-GGT } \\
\mathrm{U} / \mathrm{mg} \text { protein }\end{array}$ & $8,43+1,8$ & $4,67+0,43$ & $\mathrm{U}=36 ; \mathrm{p}<0,05^{*}$ \\
\hline $\begin{array}{l}\text { aspartat transaminaz-AST } \\
\mathrm{U} / m g \text { protein }\end{array}$ & $21800+1323,6$ & $22016,6+1990$ & $\mathrm{U}=20 ; \mathrm{p}>0,05$ \\
\hline $\begin{array}{l}\text { glutatyon S transferaz-GST } \\
\text { U/mg protein }\end{array}$ & $0,02+0,0$ & $0,02+0,0$ & $\mathrm{U}=24 ; \mathrm{p}>0,05$ \\
\hline
\end{tabular}


Böbrek, beyin ve kalp için diğer tüm enzim gruplarında enzim aktivitelerindeki değişiklik istatistiksel olarak anlamsız bulundu. $(p>0,05)$.

DES, karaciğerde glukronik asit ile suda çözünebilen glukuronit konjugatını oluşturur. DES-glukuronit safra üzerinden bağırsağa salındıktan sonra değişikliğe uğramadan geri emilip enterohepatik dolaşıma geçer (5). Dolayısı ile uzun süre vücutta varlığı saptanabilir.Bu arada DES'in enzimler üzerindeki etkileri geniş ilgi ve araştırmalara konu olmuştur . Isaksson ve ark. 3 lizozom enzimi -Hekzoaminidaz, $\beta$ - Glukorinidaz ve a-Fukozidaz- üzerinde yaptıkları incelemede enzim aktivitelerinin östrojen uygulanan ratlarda değiştiğini, ancak DES verilenlerde sadece a -Fukozidaz enzim seviyesinde farklılaşma olduğunu bildirmişlerdir (21). 1, 2 ve 3 aylık periyotlarla DES verilen deneklerde yapılan araştırmada zamana bağlı olarak adenozin deaminaz (ADA) aktivitesinde periyodik artış izlenmiştir (11-13). Nagae ve arkadaşlarının sıçan karaciğerinde yaptıkları araştırmada ise DES'in doza bağlı olarak glutamat-oksalasetat transaminaz (GOT), glutamat piruvat transaminaz (GPT) ve LDH aktivitelerini inhibe ettiği gösterilmiştir (15). Bir diğer araştırmada ise fare kas dokusu üzerine DES'in etkisi incelenmiş ve LDH inhibisyonu saptanmıştır (22) Kas dokusunda yapılan bir diğer araştırmada ise ALP aktivitesinde artış bildirilmiştir (23, 24). Sıçanlarda seks hormonlarının beyin ve karaciğer GST'sine etkisinin araştırıldığı bir çalışmada ise GST'de redüksiyon saptanmıştır (25). Nunez-Delicado ve arkadaşları ise cyclodextrin-DES kompleksi ile yaptığı araştırmada, lipoksijenaz aracılığı ile DES oksidasyonunun inhibe edildiğini göstermiş ve DES' in lokal ve sistemik yan etkilerinin azaltılmasında bu kompleksin faydalı olduğunu bildirmişlerdir (26). Sharma ve Slocum ise antioksidan etkili Vitamin C ve N-Asetil Sistein' in DES' in yapması muhtemel DNA arylasyonunu ve genotoksisiteyi önlediğini göstermişlerdir (27). İn vivo II. faz detoksifıkasyon yolu sülfasyonun araştırılması ile de sülfatlı DES türevlerinin bu yolla detoksifiye edildiği bulunmuştur (28). Van Der Heyden ve ark. ise DES'in hücre içi pH dengesini plazma membranı ATPaz'ları inhibe ederek değiştirdiğini göstermişlerdir (29).

Bizim çalışmamızda ise yapılmış olan diğer enzim çalışmalarına benzer şekilde $(15,22)$ böbrek homojenatında LDH aktivitesinde inhibisyon izlenmiş, GST enzim aktivasyonun da ise anlamlı artış bulunmuştur. Tüm dokularda GGT enzim aktivitesinin denek grubunda yüksek olması ve beyin dokusunda anlamlı artış göstermesi dikkat çekicidir. Kalpte ALT ve AST değerlerinde, beyin dokusunda ise ALT değerinde ilgi çekici azalış saptanmıştır. 
TCA döngüsündeki metabolitlerin enzimleri olan ALT, AST ve LDH değişimleri incelendiğinde istatistiksel olarak anlamlı sonuç vermemekle birlikte, ALT ve AST dalak haricinde tüm dokularda aktivite kaybına uğramış olarak görülmektedir. Bu da oksaloasetat ve piruvat yönündeki metabolik aktivitenin aspartat ve alanine yöneldiği izlenimini uyandırmıştır. Benzer şekilde LDH' de gözlenen aktivite kaybının da ALT ve AST' de olduğu gibi DES' in anabolik etkisine bağlı olduğunu düşünülebilir.

DES için yapılan pek çok araştırma mevcuttur, ancak enterohepatik dolaşıma geçip vucutta uzun süre varlığını sürdürebilmesi ve hücre içi enzim dengelerini değiştirebilmesi, genotoksisitesi gibi nedenlerden dolayı mutajenite ve toksisitesinin daha ileri tekniklerle araştırılması gerektiği kanısındayız.

\section{KAYNAKLAR}

1. Bozkurt, M. "Hayvan ürünlerinde anabolik (hormon) rezütleri ve ulusal yasal düzenlemeler" Türk Hij. Den. Biyol Derg., 45 (2); 260-287. (1988)

2. Anonim: American survey ashort of hormon, Economist Jan. 29-30 (1988)

3. Bracbill,Y., Berendes,H.W "Dangers of Diethylstilbestrol.Rewiew of a 1953 paper" Lancet (letter) 2;520(1978)

4. Şener, S "Hayvansal ürünlerde kalıntı" TÜBİTAK, Veteriner ve hayvancılık grubu özel ihtisas komisyonu raporu, Ankara (1994)

5. Ergun, H" Hormon ve hormon benzeri anabolik ajanlar" A. ̈. Vet. Fak. Dergisi 35 (2-3); 353-363 (1988)

6. Wortsman,J.,Hamıdına,A., Winters, S.S " Hypogonadism long- term treatment with DES" Am. J.Med. Sci. 297 (6); 365-368 (1989)

7. Matias-Guı X. Clear cell tumors of female genital tract. Semin Diagn Pathol. Nov;14 (4):233-9(1997)

8. Reich O. Clear cell carcinoma of the uterine cervix: pathology and prognosis surgically treated stage IB-IIB disease in women not exposed in utero DES. Gynecol Oncol. Mar; 76(3):331-5 (2000)

9. Hatch, E.,Herbst,A., Hoover,R . Incidance of squamous neoplasia of the cervix and in DES-exposed daughters. Ann.Epidemiol 1:10(7):467 (2000) 
10. Ersoy, E., Aghte,0., Ergun,Ş.H.. Üresin, T: Etlik piliçlerde DES yönünden ön çalışmalar,A. Ü. Vet. Fak. Dergisi 36(2-3); 1-20(1988)

11. Göze,İ., Yelkovan,İ., Bakır,S Dietilstilbestrol'ün adenozin deaminaz aktivitesine etkisi. TrJ.of.Biol 20: 179-182 (1996)

12. Göze,İ.,Çolak,A. Gebelik döneminde DES verilen fareler ve yavrularında ADA enzim aktivitesi ile kromozomal değişimler ve MspI enzimi ile bantalanlarının saptanması. Türk Ekopatoloji Dergisi 2(3-4):73-78 (1996)

13. Göze,İ., Bakır,S., Yelkovan,İ. Adenosine deaminase activity in DES administered rat and their offspring. T.J.Med.Res. 14(4); 125-127 (1996)

14. Nagta,S., Yamagima,M., Inove,K. Estorojen requlates peptidilarginin deaminaz levels in a rat pituatry cell line in culture.J.of.Cell Physiol 145;333-339 (1990)

15. Nagae Y., Miyamato,M., Miyamato,H; Effect of estrogen on liver plazma membrane in rats. Toxicol.Sci. 17(4): 185-195 (1992)

16. Kohigashi,K., Fukuda,Y., Imura,H. Inhibitory effect of tamoxifen on DES promoted hepatic tumorogenesis in male rats and its possible mechanism of action. J. Cancer Res 79 (11):1335-1339(1988)

17. Arora,V.K., Bhatia,A., Sood,S.K. Synergestic promoter effect of DES and Phenobarbitone in DENA induced hepatic neoplasia in rats. I.J.Med. Res.: 90 (5)9-16 (1989)

18. Ciba- Corning . Application Guide , 25066x 82 Rev.C 2/93. USA (1993)

19. Habig,W.A., Tabst,M.S., Jacoby,W.V. Glutatyon S transferase Biolchem.. 7130- 7139 (1974)

20. Sümbüloğlu,K., Sümbüloğlu,V. Biyoistatistik, Özdemir Yay .Ankara, 145-148p (1993)

21. Isaksson,A., Hultberg,B., Bergenfet,M. Lysosmal enzymes in pregnant and steroit treated rats , Horm Metab Res.20 (5); 274-277 (1988)

22. Dempsey, R., Morgan,S., Cohen,L. Reduction of enzyme efflux from skeletal muscule by DES Clin. Pharmocol. Ther Jul: 18 (1): 104-11 (1975)

23. Song SJ. Bone metabolizm in postmenopausal women and after estrogen treatemen. ChungHua Fu Chan Ko Tsa Chıh.Feb:28(2):79-8\( Pub Med alınt1) (1993)

24. Cohen,L. Morgan,J. DES effects on serum enzymes and 1zozymesin muscular dystrohy. ArckNerol. 33(7): 480-84 (1976) 
25. Das M, Agarwal AK, Seth PK. Regulation of brain and hepatic GST by sex hormones in rats. Biochem Pharmacol. Dec 1:31 (23):3927-30 (1982)

26. Nunez-Delicado E,Sojo M,Sanchez-Ferrer A, Garcia-Carmona F. Cyclodextrin as DES carrier system: charecterization of DES-cyclodextrins complexes. Pharm Res. Jun ;16 (6) : 854-8(1999)

27. Sharma M,SIocum HK. Prevention of quinone- mediated DNA arylation by antioxsidants. Biochem Biophys Res Commun. Sep 7; 262 (3):769-74 (1999)

28. Suiko M, Sakakibara Y, Liu MC. Sulfation of enviromental estrojen-like chemicals by human cytosolic sulfotransferases. Biochem Biophys Res CommunJan 7; 267(1):80-4 (2000)

29. Van Der Heyden N,Docampo R. Intracelluler pH in mammalian stage of Trypanosoma cruzi is $\mathrm{K}+$ dependent and regulated by $\mathrm{H}+-$ ATPases. Mol Biochem Parasitol .Feb 5; 105 (2000)

Başvuru Tarihi: 12.09.2000

Kabul Tarihi: 19.04.2001 